\title{
ANALISIS KUAT TARIK BELAH BETON PADA STANDAR KUAT TEKAN K.250 DENGAN MENGGUNAKAN LIMBAH PECAHAN BETON SEBAGAI PENGGANTI AGREGAT KASAR
}

\author{
SS. Purwanto ${ }^{1)}$, H.Darma Budhy ${ }^{2)}$ Andy Setiawan ${ }^{3)}$ \\ ${ }^{1)}$ Dosen Universitas Palembang, ${ }^{2)}$ Kepala Dinas PU BM - TR Prov. Sumsel \\ ${ }^{3)}$ Mahasiswa Universitas Palembang
}

\begin{abstract}
ABSTRAK
Beton merupakan bahan konstruksi yang sangat penting dan paling dominan digunakan pada struktur bangunan. Beton sangat diminati karena bahan ini merupakan bahan konstruksi yang mempunyai banyak kelebihan antara lain, mudah dikerjakan dengan cara mencampur semen, agregat halus, agregat kasar, air, dan bahan tambahan lain bila diperlukan dengan perbandingan tertentu. Untuk itu bahan konstruksi ini dianggap sangat penting untuk terus dikembangkan, salah satu inovasi adalah penggantian agregat kasar sebagai salah satu bahan penyusun beton, yakni menggunakan kembali limbah pecahan beton untuk penggunaan beton baru, menjadi alternatif bahan beton yang menguntungkan, karena agregat yang digunakan adalah agregat yang telah dibuang. Pemanfaatan kembali limbah pecahan beton akan meningkatkan umur penggunaan material dari limbah itu sendiri. Tujuan dari penelitian ini ialah untuk mengetahui kuat tarik belah beton normal dengan beton memakai bahan limbah pecahan beton dengan variasi 10\%, 20\%,dan 30\% sebagai pengganti agregat kasar dalam campuran mutu beton rencana $\mathrm{K} 250$, benda uji di cetak dengan menggunakan silinder beton dengan umur 7, 14, 21, dan 28 hari. Dari hasil uji kuat tarik belah beton yaitu pada beton normal dengan umur 14, 21, dan 28 hari didapat kuat tarik belah beton diatas kuat tarik belah beton rencana $4,82 \mathrm{~N} / \mathrm{mm}^{2}$. Kuat tarik belah beton yang dicapai oleh beton dengan menggunakan limbah pecahan beton $10 \%$ dengan umur $7,14,21$, dan 28 hari didapat kuat tarik belah beton diatas kuat tarik belah beton rencana $4,82 \mathrm{~N} / \mathrm{mm}^{2}$. Kuat tarik belah beton yang dicapai oleh beton dengan menggunakan limbah pecahan beton $20 \%$ dengan umur 21, dan 28 hari didapat kuat tarik belah beton diatas kuat tarik belah beton rencana $4,82 \mathrm{~N} / \mathrm{mm}^{2}$. Kuat tarik belah beton yang dicapai oleh beton dengan menggunakan limbah pecahan beton 30\% dengan umur 21, dan 28 hari didapat kuat tarik belah beton diatas kuat tarik belah beton rencana $4,82 \mathrm{~N} / \mathrm{mm}^{2}$.
\end{abstract}

Kata Kunci : Kuat tarik belah beton, agregat, limbah pecahan beton.

\section{PENDAhuluan}

\subsection{Latar Belakang}

Beton merupakan bahan konstruksi yang sangat penting dan paling dominan digunakan pada struktur bangunan. Beton sangat diminati karena bahan ini merupakan bahan konstruksi yang mempunyai banyak kelebihan antara lain, mudah dikerjakan dengan cara mencampur semen, agregat, air, dan bahan tambahan lain bila diperlukan dengan perbandingan tertentu. Kelebihan beton yang lain adalah, ekonomis (dalam pembuatannya menggunakan bahan dasar lokal yang mudah diperoleh), dapat dibentuk sesuai dengan kebutuhan yang dikehendaki, mampu menerima kuat tekan dengan baik, tahan aus, rapat air, awet dan mudah perawatannya, maka beton sangat populer dipakai baik untuk struktur-struktur besar maupun kecil. Untuk itu bahan konstruksi ini dianggap sangat penting untuk terus dikembangkan. Salah satu inovasi adalah penambahan maupun penggantian agregat kasar sebagai salah satu bahan penyusun beton. Kerikil atau batu pecah (split) merupakan agregat kasar yang umumnya digunakan pada campuran beton. Sudah banyak penelitian yang mengkaji tentang 
penggantian kerikil atau batu pecah (split) sebagai agregat kasar dengan bahan material yang lain, salah satunya adalah limbah hasil industri. Limbah atau bahan yang sudah tidak dapat difungsikan kembali adalah salah satu bahan material yang dapat digunakan untuk pengganti agregat kasar. Sebagai contoh limbah pecahan genteng, limbah pecahan ubin atau keramik hingga limbah pecahan beton. Menggunakan kembali limbah pecahan beton untuk penggunaan beton baru, menjadi alternatif bahan beton yang menguntungkan, karena agregat yang digunakan adalah agregat yang telah dibuang. Pemanfaatan kembali limbah beton akan meningkatkan umur penggunaan material dari limbah itu sendiri.

\subsection{Tujuan Penelitian}

Adapun tujuan penelitian ini adalah :

1. Membandingkan kuat tarik belah beton normal dengan beton memakai bahan limbah pecahan beton sebagai pengganti sebagian agregat kasar dalam campuran beton.

2. Mengetahui pengaruh limbah pecahan beton sebagai pengganti sebagian agregat kasar dengan variabel tertentu terhadap kuat tarik belah beton.

3. Untuk mengetahui nilai optimal kuat tarik belah beton pada beton dari komposisi campuran pengganti agregat kasar dari pecahan beton dengan menggunakan faktor air semen yang telah ditentukan dalam perencanaan campuran beton.

\subsection{Manfaat Penelitian}

Akan memberikan pengetahuan dan pemahaman yang lebih mendalam tentang pemanfaatan limbah pecahan beton sebagai pengganti agregat kasar pada campuran beton, sehingga mampu memberikan kontribusi yang besar dalam perkembangan teknologi beton di dunia Teknik Sipil.

\subsection{Rumusan Masalah}

Permasalahan yang akan dibahas dalam penulisan skripsi ini adalah sebagai berikut :

1. Bagaimana pengaruh limbah pecahan beton sebagai pengganti agregat kasar tersebut terhadap kuat tarik belah beton.

2. Bagaimana pengaruh perbandingan beberapa variabel campuran limbah pecahan beton sebagai pengganti agregat kasar terhadap kuat tarik belah beton.

3. Apakah dengan limbah pecahan beton dan faktor air semen yang ditentukan akan menghasilkan kuat tarik belah beton yang direncanakan.

\subsection{Batasan Masalah}

Penelitian dilakukan terhadap beton dengan membandingkan antara beton normal dengan beton yang menggunakan limbah pecahan beton sebagai pengganti agregat kasar, perlakuan yang diambil pada penelitian ini sebanyak 4 perbandingan yaitu ;

1. Beton Normal Standar Kuat Tekan K 250

2. Beton dengan menggunakan limbah pecahan beton sebagai pengganti agregat kasar sebesar $10 \%$.

3. Beton dengan menggunakan limbah pecahan beton sebagai pengganti agregat kasar sebesar $20 \%$.

4. Beton dengan menggunakan limbah pecahan beton sebagai pengganti agregat kasar sebesar $30 \%$.

5. Penelitian yang dilakukan meliputi kuat tarik belah beton. Pengujian dilakukan pada umur beton 7 hari, 14 hari 21 hari dan 28 hari.

\section{TINJAUAN PUSTAKA}

\subsection{Pengertian Beton}

Beton adalah bahan yang diperoleh dari mencampur semen, pasir, agregat kasar, air (bahan tambahan yang sangat bervariasi mulai dari bahan kimia tambahan, serat sampai bahan bangunan dan kimia dengan perbandingan tertentu) yang mengeras menjadi benda padat. Agregat merupakan bagian yang terbanyak dalam pembentukan beton sedangkan semen dan air akan membentuk pasta yang akan mengikat agregat. Tugas perekat yaitu menghubungkan pasir atau kerikil dan mengisi lubang-lubang diantaranya. Tambahan air baru memungkinkan pengikat dan pengerasan dari perekat.

\subsection{Bahan Dasar Pembentuk Beton}

Beton terutama terdiri dari tiga bahan, yaitu : semen, air dan agregat, jika diperlukan dibutuhkan bahan pembantu (admixture) untuk merubah sifat-sifat tertentu dari beton yang bersangkutan. Semen merupakan bahan 
campuran yang secara kimiawi aktif setelah berhubungan dengan air.

Agregat tidak memainkan peranan dalam reaksi kimia tersebut, tetapi berfungsi sebagai bahan pengisi mineral yang dapat mencegah perubahan-perubahan volume beton setelah selesai pengadukan. Beton pada umumnya mengandung :

1) Rongga - rongga udara $1 \%-2 \%$

2) Pasta semen ( semen + air ) $25 \%$ $40 \%$

3) Agregat ( Kasar + halus ) $60 \%-70$ $\%$

\subsubsection{Semen}

Semen yang dipakai sebagai petunjuk sekelompok bahan ikat hidrolik untuk pembuatan beton, Hidrolik berarti :

1) Semen bereaksi dengan air dan membentuk suatu satuan massa.

2) Suatu produksi keras ( batuan semen ) yang kedap air.

\section{Semen Portland}

Semen Portland yang dibuat dari semen hidrolis yang dihasilkan dengan cara menghaluskan klinker yang terutama terdiri dari silikat - silikat kalsium yang bersifat hidrolis ditambah dengan bahan yang mengatur waktu ikat (umumnya gips)

\subsubsection{Agregat}

Agregat adalah bahan - bahan campuran beton yang saling diikat oleh perekat semen. Agregat yang umum dipakai adalah pasir, kerikil, dan batu pecah.

\section{Kerikil, Pasir dan Batu Pecah}

$>$ Kerikil

I.J Kwantes dalam bukunya Ilmu Bangunan I membagi kerikil, pasir dan batu pecah ke dalam berbagai jenis sebagai berikut :

a. Kerikil yang ditemukan di dasar laut kita sebut kerikil laut.Kerikil yang bercampur dengan pasir kita sebut pasir kerikil.Kerikil terutama terdiri dari butir-butir kwarsa,batu api dan batu pasir.Mengenai ukuran kerikil,kita golongkan bubuk batu yang berukuran 2-64mm.Ini dibagi lagi dalam:

b. Kerikil kasar : 16-63 mm besar butir

c. Kerikil halus : 2-16 mm besar butir

\section{Pasir}

Satu-satunya perbedaan antara pasir dan kerikil adalah dalam ukuran butir butirnya. Pasir terjadi melalui cara yang sama seperti kerikil. Batas antara pasir dan kerikil ditentukan $2 \mathrm{~mm}$. Besar butir ditentukan 212 $2000 \mathrm{~mm}$.
a. Pasir kasar
: $600-2000$
b. Pasir setengah kasar : $212-600 \mathrm{~mm}$
c. Pasir halus
: $63-212 \mathrm{~mm}$

\section{Batu Pecah}

Bermacam-macam jenis batu bilamana dipecah, cocok untuk digunakan sebagai agregat beton. L.J. Murdock dan K.M.Brook dalam bukunya bahan dan praktek beton membedakan batu pecah dalam beberapa jenis yaitu [8] :

1. Batu Kapur adalah batuan hasil sedimentasi yang komposisi utamanya ialah kalium karbonat. Semakin keras dan padat jenis kapur ini, terutama jenis ferrokarbonat makin cocok sekali untuk pembuatan beton.

2. Batu Api meliputi granit, dolerite, basalt, gabbros dan porphyries. Istilah yang digunakan dalam perdagangan memang agak membingungkan ,karena"granit"diartikan semua jenis batu api, bahkan termasuk juga beberapa jenis batu kapur. Granit adalah keras, ulet dan padat sehingga merupakan agregat yang baik untuk beton. Basalt batu api yang menyerupai granit, tetapi struktur butirnya lebih halus karena pendinginan yang cepat pada proses pembentukannya ini merupakan agregat yang sangat baik. Dolerit mempunyai struktur butir Kristal yang halus dan mengandung feldspar banyak dan bahan lain seperti : augite, olvine dan granit.

3. Sandstone, Bilamana keras dan padat,hampir semua sandstone cocok untuk agregat. Beberapa jenis sandstone gampang pecah butirannya dan sangat berongga sehingga kurang tepat pemakaiannya sebagai agregat. Hal ini disebabkan adanya ikatan yang kurang sempurna pada butirbutir tertentu.

4. Batu Tulis biasanya agregat yang tidak baik, lunak, lemah berlapis dan daya serapnya tinggi. Lagipula bentuknya yang pipih menyebabkan partikel-partikel ini sulit dipadatkan di dalam pencetakan beton. 
5. Bahan Metamorfosa, bervariasi dalam karakternya. Marmer dan quartzites biasanya pejal, padat, serta cukup ulet dan kuat, sebagai suatu agregat yang baik. Meskipun demikian beberapa batu tulis atau sabak sering mempunyai lapisan yang tipis, sehingga tidak cocok untuk beton.

\subsubsection{Air}

Dalam pembuatan beton, air digunakan sebagi pereaksi semen menjadi pasta sehingga menjadi campuran beton tersebut menjadi mudah dikerjakan, Air yang digunakan harus bersih, tidak mengandung minyak, asam, alkali, garam, zat organik atau bahan lainnya yang bersifat perusak. Pada umumnya air dapat dipakai untuk campuran beton, namun air yang dapat digunakan untuk adukan beton tidak berarti tidak dapat diminum. Air yang mengandung zat kimia dalam batas tingkat konsentrasi tertentu masih dapat digunakan dalam adukan beton.

\subsection{Limbah Pecahan Beton}

Sangat diperlukan suatu teknologi konstruksi yang dapat mengurangi eksploitasi alam dan dapat memanfaatkan limbah-limbah beton. Salah satu contoh upaya mengurangi dampak tersebut adalah menggunakan kembali limbah beton untuk penggunaan beton baru. Penelitian ini bertujuan untuk mengetahui berapa besar pengaruh limbah beton sebagai pengganti agregat kasar terhadap kuat tarik belah beton.

\subsection{Rencana Campuran Beton}

Perencanaan campuran beton adalah suatu cara untuk menentukan perbandingan bahan-bahan campurannya sedemikian sehingga untuk keadaan tertentu dihasilkan beton dengan sifat - sifat yang diisyaratkan dan dengan harga ekonomis.

SK SNI T-15-1990-03 tentang tata cara rencana campuran beton normal mengemukakan persyaratan umum yang harus dipenuhi dalam hal perencanaan campuran adalah sebagai berikut [6]:

1. Proporsi campuran beton harus menghasilkan beton yang memenuhi persyaratan:

a. Kekentalan yang memungkinkan pekerjaan beton (Penuangan / pemadatan dan perataan) dengan mudah dapat mengisi acuan dan menutup permukaan secara serba sama (homogen)

b. Keawetan

c. Kuat tekan

d. Ekonomis

2. Beton yang dibuat harus menggunakan bahan agregat normal tanpa bahan tambahan.

Dalam perencanaan beton harus dipenuhi persyaratan :

a. Perhitungan perencanaan campuran beton harus didasarkan pada data sifatsifat bahan yang akan dipergunakan dalam produksi beton.

b. Susunan campuran beton yang diperoleh dari perencanaan ini harus dibuktikan melalui campuran coba yang menunjukkan bahwa proporsi tersebut dapat memenuhi kekuatan beton yang diisyaratkan.

\subsection{Kuat Tarik Belah Beton}

Kuat tarik belah beton merupakan salah satu parameter penting kekuatan beton. Nilai kuat tarik belah diperoleh melalui pengujian tekan di laboratorium dengan membebani setiap benda uji silinder secara lateral sampai pada kekuatanmaksimumnya. Pengujian dapat dilakukan pada skala tertentu dengan berbagai kondisi, jenis, beban maupun ukuran benda uji. Parameter kuat tarik beton secara tepat sulit untuk diukur. Suatu pendekatan yang umum untuk mengukur nilai kuat tarik beton adalah dengan pengujian kuat tarik belah beton yang umumnya memberikan hasil yang mencerminkan besarnya kuat tarik yang sebenarnya, hasilnya digunakan untuk menentukan nilai kuat tarik beton. Nilai pendekatan yang diperoleh dari hasil pengujian berulang kali mencapai kekuatan 0,50vfc'$0,60 \mathrm{vfc}$ ', sehingga untuk beton normal digunakan nilai 0,57vfc' (Dipohosodo, 1999).

Uji kuat tarik dilakukan dengan memberikan tegangan tarik pada beton secara tidak langsung. Spesimen silinder direbahkan dan ditekan sehingga terjadi tegangan tarik pada beton. Uji ini disebut juga Splitting test atau Brazillian test karena metode ini diciptakan di Brazil.

Kuat tarik belah dari benda uji dihitung dengan rumus sebagai berikut :

$F c t=2 \mathrm{P} / \pi \mathrm{LD}$

Dengan pengertian : 


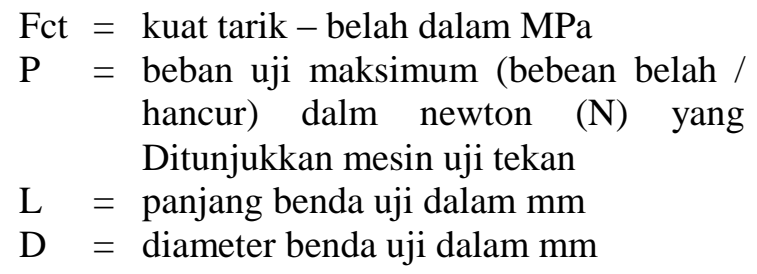

\section{METODOLOGI PENELITIAN}

\subsection{Persiapan Peralatan}

Penelitian ini dilaksanakan dilaboratorium uji bahan di Program Studi Teknik Sipil Fakultas Teknik Universitas Palembang dan Laboratorium Sipil Politeknik Negeri Sriwijaya, sebelum penelitian dilakukan perlu adanya persiapan peralatan dan bahan.

Peralatan yang digunakan berupa alat - alat untuk memeriksa agregat terdiri dari :

1) Timbangan dengan ketelitian 0,1 gram

2) Satu set saringan, untuk memeriksa agregat halus dan kasar.

3) Gelas ukur

4) Piknometer

5) Kerucut terpancung

6) Penumbuk

7) Pan aluminium

8) Pelat kaca

9) Cawan

10) Oven yang dilengkapi pengatur suhu.

11) Density spoon

12) Mesin penggetar ayakan

13) Timbangan

14) Spatula

15) Tabung silinder

16) Jangka sorong

17) Kuas

18) Ember plastic

Timbangan

2. Cawan

3. Sendok spesi

4. Cetakan beton dengan ukuran Diameter $150 \mathrm{~mm}$ x panjang $300 \mathrm{~mm}$.

5. Peralatan pengukur slump, berupa :

a) Kerucut dengan diameter bagian bawah $20 \mathrm{~cm}$, bagian atas $10 \mathrm{~cm}$, dan tinggi $30 \mathrm{~cm}$, bagian atas dan bawah cetakan terbuka.

b) Tongkat pemadat dengan diameter 16 $\mathrm{mm}$, panjang $60 \mathrm{~cm}$ ujung dibulatkan dan sebaiknya bahan tongkat terbuat dari baja atau tahan karat.
c) Plat logam dengan permukaan rata dan kedap air
d) Plat siku

6. Peralatan pengukur berat volume yang berupa :
a) Wadah baja yang berbentuk silinder dengan alat pemegang
b) Tongkat pemadat.
c) Mistar perata

\subsection{Persiapan bahan - bahan penelitian}

1) Semen Portland Padang type I

2) Agregat halus ( pasir)

3) Agregat kasar ( koral )

4) Limbah pecahan beton.

\subsection{Pemeriksaan Agregat}

\subsubsection{Pemeriksaan Agregat Halus}

Adapun pemeriksaan yang akan dilakukan untuk agregat halus yaitu berat jenis dan penyerapan, berat isi gembur dan padat, kadar lumpur, kadar air dan analisa ayak.

\subsubsection{Agregat Kasar}

Adapun pemeriksaan yang dilakukan pada agregat kasar yaitu berat jenis dan penyerapan, berat isi gembur dan berat isi padat, kadar lumpur dan analisa ayak.

\subsection{Pemeriksaan limbah pecahan beton}

Pada penelitian ini material pengganti agregat kasar yang digunakan adalah limbah pecahan beton yang dipotong - potong dengan ukuran $2 \mathrm{~cm}$ sampai $3 \mathrm{~cm}$ dengan desain pengganti agregat kasar 10\%, 20\%, dan 30\%, dari berat agregat kasar.

\subsection{Perencanaan Campuran Beton}

Metode perencanaan campuran beton yang digunakan dalam penelitian ini dengan menggunakan campuran beton dengan mutu beton rencana $\mathrm{K} 250$.

Dengan langkah kerja sebagai berikut :

1. Menentukan karakteristik kuat tekan yang diisyaratkan diambil K 250 pada umur 28 hari dengan jumlah cacat $5 \%$ dari banyak sample.

2. Menentukan deviasi standar ( $\mathrm{s}$ ) dengan melihat tabel.

3. Nilai tambah ( margin ) menggunakan rumus $=\mathrm{k} \times \mathrm{s}$ 
4. Menghitung kekuatan rata-rata yang akan dicapai dengan menjumlahkan hasil nomor $1+3$

5. Menetapkan jenis semen yang digunakan adalah semen Portland type I

6. Menetapkan jenis agregat yang dipakai adalah :

- Agregat Halus : alami

- Agregat Kasar : alami / batu pecah

7. Faktor air semen ditentukan dengan berpedoman pada grafik 1 dan 2 kemudian disesuaikan dengan type semen yang dipakai dan kekuatan tekan yang direncanakan pada umur 28 hari.

8. Faktor air semen maksimum dapat dilihat pada tabel yang disesuaikan dengan kondisi penggunaan beton tersebut.

9. Menentukan tinggi slump dengan menyesuaikan kegunaan dari beton tersebut untuk konstruksi

10. Ukuran kadar agregat ditentukan dari hasil analisa saringan dengan mengambil ukuran agregat maksimum lolos saringan

11. Kadar air bebas dapat dilihat pada tabel disesuaikan dengan besarnya slump dan ukuran agregat maksimum

12. Kadar semen tiap $m$ beton dihitung dari perbandingan air dengan factor air semen ( no $11 /$ no 7 ).

13. Kadar semen maksimum tidak ditentukan jadi dapat diabaikan

14. Kadar semen minimum ditetapkan $275 \mathrm{~kg}$ $/ \mathrm{m}^{3}$

15. Susunan besar butir agregat disesuaikan dengan analisa saringan yang ditentukan

16. Persentase agregat halus diperoleh dari perbandingan gabungan antara agregat halus dan kasar

17. Berat jenis agregat kering permukaan diperoleh dari perbandingan rata - rata berat jenis agregat halus dan kasar

18. Berat jenis beton diperoleh dari grafik degan jalan membuat grafik baru yang sesuai dengan nilai berat jenis gabungan

19. Kadar agregat gabungan $=$ berat jenis beton dikurangi jumlah kadar semen dan kadar air.

20. Kadar agregat halus $=$ persentase agregat halus ( 16 ) x kadar agregat gabungan ( no 19 )

21. Kadar agregat kasar = kadar agregat gabungan ( 19 ) dikurangi kadar agregat halus ( 20 )
Dari langkah no.1 sampai no.21, didapat susunan campuran beton teoritis untuk tiap $1 \mathrm{~m}^{3}$ yaitu diperlukan semen sebanyak (no.12), air (no.11), pasir (no.20), koral (no.21) Dalam perhitungan yang telah dilakukan, agregat halus dan agregat kasar dalam keadaan jenuh kering permukaan (SSD) maka apabila material yang ada di lapangan tidak jenuh kering permukaan harus dilakukan koreksi terhadap kebutuhan bahannya.

\subsection{Pengujian Slump}

Slump pada dasarnya merupakan salah satu pengetesan sederhana untuk mengetahui workability beton segar sebelum diterima dan diaplikasikan dalam pekerjaan pengecoran.

Adapun langkah pengerjaannya adalah sebagai berikut :

1. Kerucut terpancung dan pelat dibasahi dengan kain basah

2. Letakkan kerucut terpancung di atas pelat.

3. Isilah kerucut terpancung sampai penuh dengan beton segar dalam 3 lapisan, setiap 25 kali tumbukkan secara merata. Pada pemadatan, tongkat harus tepat masuk sampai lapisan bagian bawah tiap lapisan.

4. Segera setelah selesai pemadatan ratakan permukaan benda uji dengan tongkat ,tunggu selama 30 detik dan dalam jangka waktu ini semua benda uji yang jatuh disekitar kerucut harus disingkirkan.

5. Kemudian angkat kerucut secara perlahanlahan ke atas secara tegak lurus.

6. Ukurlah slump yang terjadi dengan menetukan penurunan benda uji terhadap puncak kerucut terpancung.

Perhitungan : Besar Slump = Tinggi Penurunan Benda Uji

\subsection{Pengujian Berat Isi Beton}

Adapun langkah pengerjaannya adalah sebagai berikut :

1. Basahi takaran volume campuran beton segar dengan air

2. Tuangkan campuran beton segar ke dalam takaran tersebut sampai penuh dalam 3 lapisan,tiap lapis berisi kira-kira $1 / 3$ isi takaran tersebut.Setiap lapis dipadatkan dengan 25 tumbukkan secara merata .Pada pemadatan,tongkat harus masuk sampai lapisan bagian bawah tiap-tiap lapis.

3. Bersihkan bibir takaran dari campuran beton yang menempel, kemudian timbang. 
4. Buang campuran beton segar dari takaran kemudian dibersihkan.

5. Timbang takaran dalam keadaan kosong.

Perhitungan :

Berat Beton Segar + Berat Takaran berisi

Beton Segar - Berat Takaran (silinder)

Volume takaran $=$ Volume silinder

$$
\begin{gathered}
\mathrm{V}=\frac{1}{4} \pi \cdot D^{2} \cdot t \\
\text { Berat isi BetonSegar }= \\
\text { Berat beton segar }(\mathrm{kg}) \\
\text { Volume takaran }(\text { silinder }) \mathrm{m}^{3}
\end{gathered}
$$

\subsection{Pembuatan Benda Uji}

Adapun langkah , pengerjaannya adalah sebagai berikut:

1. Menghitung proporsi bahan campuran sesuai dengan mix design

2. Menyiapkan masing-masing bahan campuran sesuai berat proporsi

3. Masukkan semen dan agregat ke dalam bak aduk kemudian aduk hingga tercampur rata.

4. .Masukkan air sedikit demi sedikit sambil terus diaduk sampai keseluruhan air yang telah dihitung habis.

5. Pengadukan dilakukan sampai adukan beton homogen.

\subsection{Perawatan Benda Uji}

Setelah beton mengeras atau beton tersebut berumur $1 \times 24$ jam, beton dibuka dari cetakan. Pada saat membuka cetakan usahakan tidak ada getaran yang dapat menganggu proses pengerasan dan pengikatan beton. Setelah beton dibuka dari cetakan kemudian beton tersebut direndamkan dalam air selama umur beton yang diperhitungkan. Perendaman ini bertujuan untuk membantu proses pengerasan beton tersebut. Pada proses perendaman berfungsi untuk mengisi ronggarongga yang ada pada beton, air beraksi dengan semen sehingga tidak ada rongga / pori yang belum terisi benar oleh adukan maka reaksi dari semen dan air tersebut akan menutup pori tersebut. Dengan perendaman ini maka diharapkan kekuatan yang ditargetkan dapat dicapai. pada perendaman ini juga dijaga agar jangan sampai beton mengalami getaran / gangguan yang dapat menganggu pengerasan.

\subsection{Pengujian Kuat Tarik Belah Beton}

Setelah beton mengalami masa perendaman atau pemeliharaan, jika sudah mencapai umur yang direncanakan maka beton tersebut harus diangkat dari perendaman .Setelah itu kubus beton dikeringkan dari air kemudian ditimbang untuk mengetahui berat isi dari beton keras, kemudian setelah itu dilakukan pengujian kuat tarik belah beton dengan menggunakan Tensile Spliting Test (TST). yaitu suatu pembelahan silinder oleh suatu desakan kearah diameternya untuk mendapatkan kuat tarik belah. Pada mesin penguji ditambahkan suatu batangan agar dapat membagi beban merata pada panjang silinder. Dari beban maksimal yang diberikan kekuatan tarik belah dihitung sebagai berikut :

$$
\begin{aligned}
\mathrm{F}_{\mathrm{ct}} & =2 \mathrm{P} / \pi \mathrm{LD} \\
\operatorname{dimana} & : \mathrm{f}_{\mathrm{ct}}=\text { kekuatan tarik belah } \\
\left(\mathrm{N} / \mathrm{mm}^{2}\right) & \\
\mathrm{P} & =\text { beban maksimal }(\mathrm{N}) \\
\mathrm{l} & =\text { panjang silinder }(\mathrm{mm}) \\
\mathrm{d} & =\text { diameter }(\mathrm{mm})
\end{aligned}
$$

Pengujian kuat tarik belah beton dilakukan pada beton yang telah mencapai umur yang direncanakan. Pengujian ini dilakukan untuk mengetahui kekuatan yang dicapai beton tersebut pada umur tertentu apakah hasilnya sesuai dengan yang direncanakan sesuai dengan proporsi yang dicampurkan. Pengujian kuat tarik belah beton dilakukan sampai beton tersebut tidak mampu lagi memikul beban yang diberikan oleh mesin penguji kuat tarik belah beton. Jika sudah didapat hasil dari pengujian kuat tarik belah beton maka langkah selanjutnya tinggal menganalisis beberapa kuat tarik belah beton yang didapat dari proporsi yang direncanakan.

\section{Hasil dan Pembahasan}

\subsection{Analisis Pemeriksaan Agregat Halus}

Pengujian bersekala laboratorium yang dilakukan untuk agregat halus meliputi berat isi gembur dan berat isi padat, analisa saringan, berat jenis dan penyerapan, kadar lumpur dan kadar air, agregat halus yang digunakan adalah pasir sungai musi.

Dari hasil pemeriksaan yang telah dilakukan di laboratorium, didapat data - data sebagai berikut : 


\section{Agregat Halus}

Tabel 4.1. Data-data Agregat Halus

\begin{tabular}{|c|l|c|}
\hline No & \multicolumn{1}{|c|}{ Uraian } & Keterangan \\
\hline 1 & Berat Jenis (Bulk) & 2,50 \\
2 & Berat Jenis Kering & 2,52 \\
3 & Permukaan Jenuh & 2,55 \\
4 & Berat Jenis Semu & $0,83 \%$ \\
5 & Apparent & $1,34 \%$ \\
6 & Penyerapan & 2,86 \\
& Kadar Lumpur & \\
& Kehalusan & \\
\hline
\end{tabular}

Sumber : Hasil Perhitungan

\section{Agregat Kasar}

Tabel 4.2. Data-data Agregat Kasar

\begin{tabular}{|c|l|c|}
\hline No & \multicolumn{1}{|c|}{ Uraian } & Keterangan \\
\hline 1 & Berat Jenis (Bulk) & 2,58 \\
2 & Berat Jenis Kering & 2,61 \\
3 & Permukaan Jenuh & 2,66 \\
4 & Berat Jenis Semu & $1,28 \%$ \\
5 & Apparent & 3,30 \\
& Penyerapan & \\
& Kehalusan & \\
\hline
\end{tabular}

Sumber : Hasil Perhitungan

\subsection{Hasil pengujian slump beton}

Adapun hasil pengujian slump beton dapat dilihat pada tabel 4.3. berikut :

Tabel 4.3. Nilai pengujian slump

\begin{tabular}{|c|c|}
\hline Beton & $\begin{array}{c}\text { Nilai slump } \\
(\mathrm{cm})\end{array}$ \\
\hline Normal & 11,17 \\
\hline Pengganti Agregat Kasar 10\% & 9,3 \\
\hline Pengganti Agregat Kasar 20\% & 7,7 \\
\hline Pengganti Agregat Kasar 30\% & 7 \\
\hline
\end{tabular}

Grafik Pengujian Slum

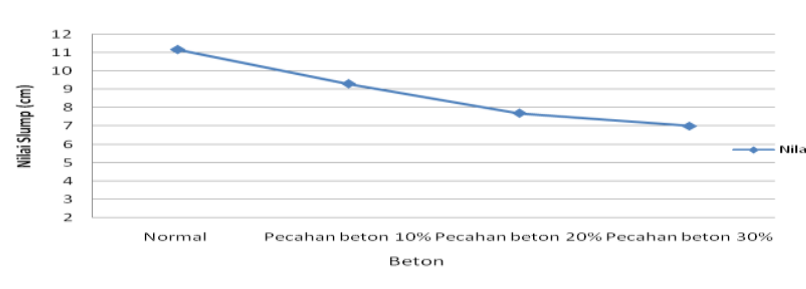

Grafik 4.1. Grafik Pengujian Slump

Analisis Kuat Tarik Belah Beton Pada Standar Kuat Tekan K250 Dengan Menggunakan Limbah
Berdasarkan grafik tersebut dapat diketahui bahwa slump yang di capai mulai dari beton normal, beton dengan material pecahan beton sebagai bahan pengganti agregat kasar 10\%, 20\%, 30\% masih memenuhi slump yang disyaratkan antara $60-$ $100 \mathrm{~mm}$.

\subsection{Pengujian Kuat Tarik Belah Silinder Beton}

Pengujian kuat tarik belah silinder beton dilakukan pada umur 7, 14, 21 dan 28 hari dengan memberikan tegangan tarik pada beton. Kekuatan tarik belah beton relatif rendah, kira-kira 10\%-15\% dari kekuatan tekan beton. Pada dasarnya pengujian kuat tarik belah beton mengacu pada SNI 03-24912002 "Metode Pengujian Kuat Tarik Belah Beton".

Tabel 4.4. Rekapitulasi kuat tarik belah beton

\begin{tabular}{|l|c|c|c|c|}
\hline \multirow{2}{*}{$\begin{array}{c}\text { Kuat tarik } \\
\text { belah beton } \\
\text { rata-rata }\end{array}$} & \multicolumn{4}{|c|}{ Variasi } \\
\cline { 2 - 5 } & Normal & $\begin{array}{l}\text { Pengganti } \\
\text { Agregat } \\
\text { Kasar 10\% }\end{array}$ & $\begin{array}{l}\text { Pengganti } \\
\text { Agregat } \\
\text { Kasar 20 \% }\end{array}$ & $\begin{array}{l}\text { Pengganti } \\
\text { Agregat } \\
\text { Kasar 30 \% }\end{array}$ \\
\hline $\begin{array}{l}\text { Umur } \\
\text { hari }\end{array}$ & 4,81 & 4,96 & 4,07 & 3,48 \\
\hline $\begin{array}{l}\text { Umur 14 } \\
\text { hari }\end{array}$ & 5,48 & 5,41 & 4,74 & 4,30 \\
\hline $\begin{array}{l}\text { Umur 21 } \\
\text { hari }\end{array}$ & 6,07 & 5,78 & 5,33 & 4,96 \\
\hline $\begin{array}{l}\text { Umur 28 } \\
\text { hari }\end{array}$ & 6,52 & 6,44 & 6,00 & 5,56 \\
\hline
\end{tabular}

Sumber : Hasil penelitian

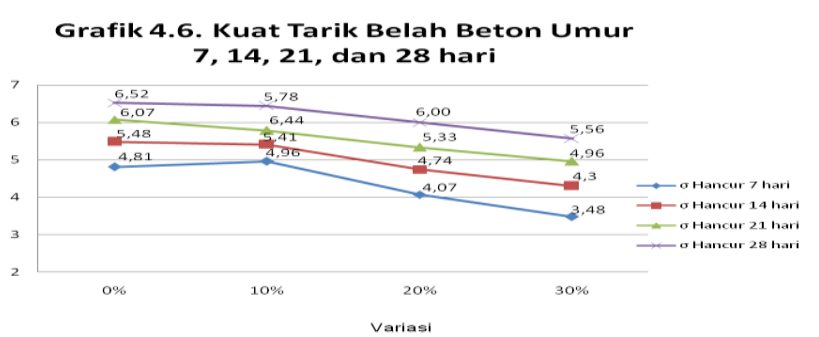

V. KESIMPULAN DAN SARAN 5.1. Kesimpulan

Berdasarkan hasil penelitian dan pembahasan yang telah diuraikan sebelumnya, penulis dapat menarik kesimpulan sebagai berikut : 
1. Nilai evaluasi kuat tarik belah beton yang dicapai oleh beton tanpa menggunakan material pengganti agregat kasar atau beton normal pada umur 7, kuat tarik belah belum tercapai $4,81 \mathrm{~N} / \mathrm{mm}^{2}$, setelah 14,21 , dan 28 hari didapat semuanya diatas kuat tarik belah beton rencana $4,82 \mathrm{~N} / \mathrm{mm}^{2}$.

2. Nilai evaluasi kuat tarik belah beton yang dicapai oleh beton dengan menggunakan limbah pecahan beton atau material pengganti agregat kasar $10 \%$, kuat tarik belah beton pada umur 7, 14, 21, dan 28 hari didapat semua kuat tarik belah di atas kuat tarik belah rencana $4,82 \mathrm{~N} / \mathrm{mm}^{2}$.

3. Nilai evaluasi kuat tarik belah beton yang dicapai oleh beton dengan menggunakan limbah pecahan beton atau material pengganti agregat kasar 20\% kuat tarik belah beton pada umur 7, dan 14, hari kuat tarik belah belum tercapai, setelah 21, dan 28 hari kuat tarik belah baru meningkat bahkan di atas kuat tarik belah rencana.

4. Nilai evaluasi kuat tarik belah beton yang dicapai oleh beton dengan menggunakan limbah pecahan beton atau material pengganti agregat kasar 30\% kuat tarik belah beton pada umur 7, dan 14, hari kuat tarik belah belum tercapai, setelah 21, dan 28 hari kuat tarik belah baru meningkat bahkan di atas kuat tarik belah rencana 4,82 $\mathrm{N} / \mathrm{mm}^{2}$.

\subsection{Saran}

Setelah melakukan penelitian ini, penulis mempunyai saran yang mungkin dapat berguna bagi penelitian selanjutnya, yaitu :

> Perlu dilakukan penelitian lanjutan dengan variasi persentase limbah pecahan beton atau pengganti agregat kasar yang berbeda.

$>$ Perhatikan umur rendaman atau perawatan benda uji, karena sangat berpengaruh pada waktu pengujian.

$>$ Perlu kiranya diteliti nilai kuat tekan beton dengan limbah pecahan beton sebagai pengganti sebagian agregat kasar.

\section{DAFTAR PUSTAKA}

[1] Anon, 1982, Persyaratan Umum Bahan Bangunan di Indonesia (PUBI 1982), Pusat Penelitian Dan Pengembangan PU, Bandung.

[2] SK SNI T-15-1991-03 Tata Cara Perhitungan Struktur Beton Untuk
Bangunan Gedung, Badan Standarisasi Nasional

[3] Teknologi Bahan II, PEDC Bandung 2. EDC, EDC CI CNS, 1987 : hal:6

[4] TEDC Bandung,Teknologi Bahan 3 Edisi I, 1983

[5] Murdock L.J., Book, K. M.,1986. Bahan dan Praktek Beton, Terjemahan Ir. Stephanus Hindarko, Erlangga, Jakarta

[6] SK SNI T-15-1990-03 Tata Cara Pembuatan Rencana Campuran Beton Normal, Badan Standarisasi Nasional

[7] SK SNI S-04-1989-F Tentang Spesifikasi Aggregat sebagai bahan bangunan Normal, Badan Standarisasi Nasional

[8] Murdock, L.J. and Brook, K.M. dan Hendarko, S. 1378. Bahan dan Praktek Beton. Erlangga

[9] SNI 03-1974-1990 Metode Pengujian Analisa Saringan Agregat Halus dan Kasar, Badan Standarisasi Nasional

[10] SNI 1969:2008 Cara Uji Berat Jenis dan Penyerapan Air Agregat Kasar, Badan Standarisasi Nasional

[11] SNI 03-2491-2002 Metode pengujian kuat tarik belah beton, Badan Standarisasi Nasional

[12] Sugiyono, 2008, Metode Penelitian Kuantitatif, Kualitatif dan R\&D, Bandung 